\title{
NEETs in Europe: from Plural (In)visibilities to Public Policies
}

\author{
Maria Manuel Vieira $^{1} \cdot$ Lia Pappámikail $^{2} \cdot$ Tatiana Ferreira $^{2}$ \\ Published online: 6 July 2021 \\ (C) The Author(s), under exclusive licence to Springer Nature Singapore Pte Ltd. 2021
}

\section{Editors' Introduction}

In recent decades, a considerable amount of research on youth transitions (Brooks 2009; du Bois-Reymond and Chisholm 2006; Pais and Ferreira 2010) has pointed to the complexity of contemporary young people's lives, as progression into adulthood has become increasingly prolonged, fragmented and largely unpredictable. More recently, the high level of youth unemployment rates observed during the economic crisis became a matter of deep concern for political authorities at the global level (Bendit and Miranda 2015; Eurofound 2012; Inui 2005; Longo and Gallant 2016; Longle 2016; Henderson et al. 2017; Jacinto 2016).

In Europe, unemployment has hit the young population hard. A peak of $24.4 \%$ average unemployment was observed in the EU27 in 2013, but in some Member States, the rate reached $50 \%$ and addressing youth unemployment became a top political priority. From 2014 onwards, the EU authorities launched the largest financial package specifically targeted at the youth population (Europe 2020 flagship initiative Youth on the Move), as it aimed to enhance the performance of education systems, boost job creation and facilitate the entry of young people into the labour market.

The world, and Europe in particular, has since then experienced a short period of prosperity, which temporarily lowered unemployment rates among young people and also eased the social alarm around youth in general. The pandemic crisis, however, has abruptly cut off this trend, bringing young people's problems again onto the public and political agenda, underlining their structural nature, as the literature has systematically pointed out. Unemployment has risen significantly all over Europe since the COVID19 pandemic (in the 4th quarter of 2020 youth unemployment reached $17.1 \%$ and NEET rates, which had fallen continuously in recent years, reached 11\%), but this was

Lia Pappámikail

lia.pappamikail@ese.ipsantarem.pt

1 Institute of Social Sciences, University of Lisbon, Lisbon, Portugal

2 School of Education, Polythechnic Institute of Santarém, Santarém, Portugal 
not the only problem, as educational and mental health issues, for example, are also of concern (Eurofound 2020).

In this context, the NEET rate - a statistical construct "made in Europe" in the late 1990s to capture the share of young people Not in Employment, Education or Training - gained new relevance. Having emerged as an indicator aimed at estimating the prevalence of both schooling and labour market vulnerability among young people (Eurofound 2012) and consequently at underpinning public policy and government actions, it has been widely disseminated in recent years.

The NEET rate raises a number of problems, some of which have been pointed out in recent academic literature (Guénard et al. 2016; Vieira et al. 2018; Wong 2016). In fact, the indicator takes on different meanings according to each country's cultural specificity (e.g. the official NEET definition in Japan differs from that used in Europe) so that youth realities are non-comparable. It covers a broad range of trajectories and situations, too heterogeneous to represent a truly common experience. Moreover, the indicator produces a moral judgement since it presents NEETs as being in social deficit: they do not meet ("not in...") the standard pattern for the social integration of youthbeing either in school or at work-nor do they fit into the dichotomous statistical category of the unemployed or inactive. In sum, research has systematically revealed this indicator's shortcomings, and a considerable amount of literature has pointed out its weaknesses (Cuzzocrea 2014; Follesø 2015; Holte 2017).

Little research, though, has gone beyond the criticism of the NEET construct, exploring the new youth experiences and realities that gave rise to the initial concern - the fact that some young people fly under the statistical and/or institutional radars (Furlong 2006). Indeed, while the NEET statistical construct emerged to capture an elusive or even "missing" population, we now know that it has also contributed to casting a shadow of invisibility on some groups within this young population and their forms of existence and resistance (Ferreira 2016; Gaspani 2018).

In contrast, the stereotypical conception of young people not in education, employment or training, largely fed by the media, rendered some specific groups of young people in this situation overly visible, often making them the sole focus of attention of both policymakers and youth and social workers, neglecting the diversity of young people not in education, employment or training realities and experiences.

Some critical questions therefore arise: if young people not in education, employment or training are neither at school nor at work, where are they after all? How are they building their trajectories away from traditional institutions like schools and the labour market? What are these young people's perspectives of the situation in which they find themselves? Are the standard statistical tools used to collect information on young people's lives suitable for capturing emerging realities (for example, can they address increasing exploitation ethics; new subjective engagements; the use of social media as new platforms of learning, economic activity and connectivity?)

Anchored to a rather blurred picture of the contemporary youth condition, public policies tend to classify all young people who deviate from a normative trajectory as being at risk or in a situation of social exclusion, as they may shake up the European social model and the intergenerational contract that sustains it (Farrugia et al. 2015). By putting the focus on "rescuing" young people, youth policies risk becoming biased approaches, with poor results. 
This special issue brings together a set of multidisciplinary contributions aimed at on the one hand, at fostering an understanding of who the young people not in education, employment or training are and what it means to be NEET in different European countries and, on the other hand, at questioning the paradoxes and contradictions surrounding public policies designed to address them. The authors come from disciplinary backgrounds as diverse as Social Psychology, Sociology, Anthropology and Political Science, and their empirical research involves methodological options associated with various analytical scales and different research techniques. From case studies involving one individual to researchers dealing with large population groups, the set of papers included in this issue offers a comprehensive approach to critical issues involving young people not in education, employment or training. Launched before the current pandemic crisis, this issue was at risk of becoming outdated, given the dramatic changes it brought to everybody's lives - including young people. Nevertheless, not only are most of the results brought to light in this issue surprisingly current, but some authors also sought to create bridges between their research results and the challenges we are experiencing in the times since COVID.

\section{Articles in this Special Issue}

The first article included in this thematic issue, "Mapping young NEETs across Europe: Exploring the institutional configurations promoting youth disengagement from education and employment" by Marie-Luise Assmann and Sven Broschinski, addresses the NEETs in Europe theme from a statistical indicator perspective. The economic crisis caused high rates of youth unemployment in many European countries, leading to a climate of social alarm and the emergence of several public policies anchored in the statistical construct of young NEETs. This article seeks to contribute to the discussion of the uses and relevance of this statistical indicator, its heterogeneity and differences across Europe. Based on aggregated EU Labour Force Survey data from 2018, it explores how the rates of different NEET subgroups are conditioned by various institutional configurations, by applying fuzzy-set quantitative comparative analysis for 26 European countries. The analysis unveils the different barriers young people face across Europe and the urgency in developing country-specific measures in order to reduce the number of young people not in education, employment or training in Europe, overcoming the limitations of European policies.

The next two articles examine the public policies designed to deal with young people not in education, employment or training. Comparing official statistical data on the relationship between young people and the labour market with policy, academic and public discourse on young people not in education, employment or training, Tanja Strecker, Joffre López and M. Àngels Cabasés discuss the impact of the stereotypical representation of these young people and the use of the term itself in the definition of the policy responses designed to tackle this issue. They argue that a "deficit perspective" contributes to enhancing young people's invisibility and to producing short-term policy remedies based on providing further education and skills, thus diverting attention away from the real structural problems that afflict young people in countries like Spain. One of the most significant of these is job insecurity, which accounts for the labour market instability that puts young people in the state of being NEET. 
Likewise, Charlotte McPherson's article "Between the rhetoric of employability and the reality of youth (under) employment: NEET policy rhetoric in the United Kingdom and Scotland" also explores the theme from the point of view of policies targeted at young people not in education, employment or training. Using critical discourse analysis (CDA), this article examines policy rhetoric between the Scottish and UK governments in relation to young people labelled as NEET. Contrary to the common belief that there is a political and policy divergence between the UK and Scottish administrations, the analysis of a range of policy documents relating to young people and NEET shows that "the rhetoric that underpins NEET policy is in fact more similar than it is different between the two neighbouring nations".

The next article "Time to work - opposing political rationality with young peoples' experiences of working in a mandatory activation context in Norway" focuses on temporality as the analytical lens for the research undertaken. Heidi Moen Gjersøe and Anne Leseth compare the (normative) representation of time that the political rhetoric of "activation" enshrines in the programmes aimed at integrating disadvantaged young people not in education, employment or training into the labour market and the non-linear lived experiences of work which these young people perform. The optimal (rational) temporality of "rescuing" them from being NEET, measured in political terms by the speed of their integration into the labour market, does not take into account the complexity and vulnerability that this represents for these young adults, leading them to what some call "yo-yo trajectories" (getting a job, having a job, losing a job).

The last two articles focus on young NEETs as subjects of public policies, on the mutable and plural character of this NEET status and on their agency, in two countries with contrasting welfare systems: Italy and Norway. Italy is a country where informal and family support networks play a decisive and growing part in young peoples' lives and trajectories, and where institutional support, through youth policies and the welfare state in general, has declined over recent decades. The article "An Analysis of Social Relationships' Quality Associations with Hope Among Young Italians: the Role of NEET Status" looks at hope, described in terms of Basic Psychological Needs Satisfaction (BPNS), as an important contribution to understanding agency vis-a-vis life projects of young Italians not in education, employment or training in comparison with the general youth population. Unveiling the intrinsically social and individual nature of hope, using extensive data collected by the Youth Report from the Osservatorio Giovani of the Istituto Toniolo di Studi Superiori, Simões and colleagues demonstrate how young people not in education, employment or training, and those less satisfied with their education and financial situation have lower levels of agency than their less vulnerable counterparts. This social psychology study makes it possible to question how the weight of informal support networks - which are particularly permeable to social inequalities, when linked with young NEETs' profiles and characteristics in Italy - reinforces the social disadvantages and vulnerabilities of these young people, in the absence of more effective investment in public policies.

Can NEET realities and the paradoxes of the public responses be discussed on the basis of one individual's story? Bjørn Hallstein Holte's article “Aalan's story: Categories of youth research and policy in young people's lives" is a good example of this. Anchored in an anthropological perspective, this article presents a young man living in a suburb of Oslo who at one time or another fell into different social and social policy 
categories and was "handled"- and sometimes supported and/or subject to intervention-accordingly. Holte discusses the problem of (in)visibility, both in youth research and policy levels, and how institutional support is managed according to rigid bureaucratic rules and normative prescriptions, many times ignoring young people's situations, expectations and, more importantly, needs. Aalan's story, shifting from the hyper-visible category of youth at risk to being part of an invisible category of NEET young people unveils policy gaps and institutional mismatches which have a significant impact on young peoples' lives, especially for those on the margins.

Together, this special issue provides a contemporary critique of current definitions, policies and practices towards NEET young people in Europe, with the aim of widening our understandings and ability to respond with more inclusive, ethical and life-enhancing strategies for all young people, regardless of the limiting statistical or policy categories in which they fall temporarily or permanently. Starting from the intrinsic diversity of young people to whom public policies are addressed, and by taking into account their experiences, points of view, constraints and expectations, the issue contributes to question, and thus enriches, the adult-centric institutional and normative approaches usually produced about NEET young people, thus exposing the complex (in)visibilities that make contemporary youth.

\section{References}

Bendit R, Miranda A (2015) Transitions to adulthood in contexts of economic crisis and post-recession. The case of Argentina. J Youth Stud 18(2):183-196

Brooks R (ed) (2009) Transitions from education to work: new perspectives from Europe and beyond. Palgrave Macmillan, Hampshire

Cuzzocrea V (2014) 'Projecting the category of the NEET into the future', In AAVV, Perspectives on Youth. 2020 - what do YOU see?, vol.1. Strasbourg: European Youth Partnership, Council of Europe and European Commission. pp 69-82. http:/youth-partnership-eu.coe.int/youthpartnership/publications/ Perspectives/PoY1

du Bois-Reymond M, Chisholm L (eds) (2006) The modernization of youth transitions in Europe. JosseyBass, San Francisco

EUROFOUND (2012) NEETs - young people not in employment, education or training: characteristics, costs and policy responses in Europe. Publications Office of the European Union, Luxembourg

EUROFOUND (2020) Living, working and COVID-19, COVID-19 series, Publications Office of the European. Union, Luxembourg

Farrugia, D., SMYTH, J., and HARRISON, T. (2015). 'Vulnerable', 'atrisk', 'disengaged': regional young people. In Kitty te Riele and Radhika Gorur (eds.). Interrogating conceptions of 'vulnerable youth' in theory, policy and practice. Innovations and Controversies: Interrogating Educational Change (2). Rotterdam: Sense Publishers. https://doi.org/10.1007/9789463001212_11

Ferreira VS (2016) Aesthetics of youth scenes: from arts of resistance to arts of existence. Young. 24(1):66-81

Follesø R (2015) Youth at risk or terms at risk? Young 23(3):240-253

Furlong A (2006) Not a very NEET solution: representing problematic labour market transitions among early school-leavers. Work Employ Soc 20(3):553-569

Gaspani F (2018) Young adults NEET and everyday life: time management and temporal subjectivities. Young 27(1):69-88

Guénard C, Giret J-F, Joseph O, Murdoch J (2016) Une recherche sur les jeunes NEET en France. Observatoire Jeunes et Société 13(2):11-12

Henderson JL, Hawke LD, Chaim G (2017) Not in employment, education or training: mental health, substance use, and disengagement in a multi-sectoral sample in service-seeking Canadian youth. Child Youth Serv Rev 75:138-145 
Holte BH (2017) Counting and meeting NEET young people: methodology, perspective and meaning in research on marginalized youth. Young 26(1):1-16

Inui A (2005) Why freeter and NEET are misunderstood recognizing the new precarious conditions of Japanese youth. Social work and society 3(2):244-251

Jacinto C (2016) Débats latino-américans sur les NINI. Observatoire Jeunes et Société 13(2):14-15

Longle P (2016) Les "NEET", la valeur emploi et les catégories d'action publique dans le champ de la jeunesse en France. Observatoire Jeunes et Société 13(2):12-13

Longo ME, Gallant N (2016) Les jeunes ni en emploi, ni aux études, ni en formation (NEEF). Questions sur une catégorie de politiques publiques. Observatoire Jeunes et Société 13(2):1-2

Pais JM, Ferreira VS (eds) (2010) Tempos e transições de vida: Portugal ao espelho da Europa. Imprensa de Ciências Sociais, Lisboa

Vieira MM, Pappámikail L, Ferreira T (2018) Jóvenes y políticas juveniles: Algunos desencuentros El caso del sistema de garantía juvenil en Portugal. Metamorfosis: Revista del Centro Reina Sofía sobre Adolescencia y Juventud 9:67-88. https://revistametamorfosis.es/index.php/metamorfosis/article/view/93

Wong M (2016) The characteristics of youth not in education, employment or training (NEET) in Australia and Japan. Japan Institute for Labour Policy and Training, Tokyo 